\title{
Tanggung Renteng dalam Perkara Perdata \\ Pencemaran Udara dari Kebakaran Hutan dan lahan
}

\author{
Fajri Fadhillah ${ }^{1}$
}

\begin{abstract}
Abstrak
Kebakaran hutan dan lahan (karhutla) yang terjadi di Indonesia selain menimbulkan kerusakan lingkungan hidup juga menimbulkan pencemaran udara. Kerugian atas terjadinya pencemaran udara dari karhutla sangat besar, meliputi berbagai bidang seperti kesehatan dan pendidikan. Namun belum pernah ada gugatan ke pengadilan terhadap pelaku pencemaran udara dari karhutla tersebut. Tulisan ini bertujuan untuk mengetahui kemungkinan korban pencemaran udara dari karhutla menuntut ganti rugi secara perdata terhadap beberapa pelaku pencemaran udara dari karhutla. Tulisan ini menggunakan metode penulisan yuridis normatif berdasarkan pada peraturan perundang-undangan yang berlaku di Indonesia sebagai bahan hukum primer. Tulisan ini juga bersumber pada teori dari literatur-literatur hukum dan informasi dari internet yang menjadi bahan hukum sekunder. Tulisan ini menunjukan bahwa gugatan perdata terhadap beberapa pelaku pencemaran udara dari karhutla dapat dilakukan. Gugatan tersebut dapat dilakukan dalam bentuk gugatan tanggung renteng (joint and several liability). Selain itu, pertanggungjawaban mutlak dan asas kehati-hatian dapat menjawab tantangan pembuktian kausalitas dalam gugatan ini.
\end{abstract}

1 Penulis kini bekerja sebagai asisten peneliti di Indonesian Center for Environmental Law (ICEL). ICEL beralamat di Jalan Dempo II No. 21, Kebayoran Baru, Jakarta Selatan 12120. Penulis memiliki perhatian khusus pada bidang studi hukum pencemaran lingkungan. Penulis memperoleh gelar sarjana hukum dari Universitas Indonesia pada Februari 2015. 
Kata kunci: pencemaran udara, kebakaran hutan dan lahan, tanggung renteng, kausalitas

\begin{abstract}
Forest and land fires phenomena in Indonesia inflicted to air pollution besides the environmental harm. Injuries stemmed from the forest fires air pollution was somewhat huge, comprise to various sectors such as health and education. Unfortunately, there is no legal action alleging the air pollution tortfeasors from forest and land fires to the court until now. This article aims to see any possibilities that air pollution from land and forest fires victims could file a lawsuit against multiple tortfeasors. This article employed a normative study based on the enacted law in Indonesia as a primary source. This article also based on theories from kinds of law literature and information from the internet as a secondary source. This article shows that there is a possibility to file a civil lawsuit against multiple tortfeasors who causing an air pollution from land and forest fires. The civil lawsuit could be conducted in a joint and several liability formulation. Furthermore, strict liability and precautionary principle could answer the challenge arising from causation aspect in this particular case.
\end{abstract}

Keywords: air pollution, forest and land fires, joint and several liability, causation

\title{
I. Pendahuluan
}

Kerugian ekonomi akibat kebakaran hutan dan/atau lahan (karhutla) di Indonesia pada tahun 2015 menjadi yang tertinggi sepanjang sejarah. Kerugian ekonomi akibat karhutla pada tahun tersebut mencapai angka 221 triliun rupiah. ${ }^{2}$ Bahkan kerugian sebesar 221 triliun rupiah tersebut belum termasuk hitungan kerugian dari dampak terhadap kesehatan dan pendidikan. ${ }^{3}$ Angka 221 triliun rupiah tersebut lebih besar dua kali lipat dibandingkan dengan kerugian ekonomi akibat bencana gempa dan tsunami yang terjadi di Aceh pada tahun 2004 silam. ${ }^{4}$

Lebih mengerucut lagi, dampak karhutla terhadap kesehatan publik juga

2 “Longsor Paling Mematikan", Kompas, 19 Desember 2015.

3 Ibid.

$4 \quad$ Ibid. 
tak kalah mencengangkan. Sebanyak 24 orang meninggal dan lebih dari 600.000 jiwa menderita Infeksi Saluran Pernafasan Akut (ISPA) akibat terjadinya karhutla. ${ }^{5}$ Angka mengenai jumlah korban tersebut menjadi hal yang tidak mengherankan jika melihat fakta berikut ini: pada periode bulan September sampai Oktober 2015, masyarakat di Provinsi Riau, Jambi, Sumatera Selatan, Kalimantan Tengah, dan Kalimantan Barat menjalani kehidupan sehari-hari dengan kualitas udara yang sangat berbahaya. ${ }^{6}$

Dampak pencemaran udara dari karhutla yang dirasakan oleh sekian banyak orang tersebut terjadi tentu bukan tanpa sebab. Berdasarkan catatan Wahana Lingkungan Hidup Indonesia (Walhi), terdapat sekitar 423 perusahaan diduga terlibat langsung dalam karhutla di tahun 2015. ${ }^{7}$ Hasil investigasi yang dilakukan Eyes on the Forest di Provinsi Riau dalam kurun waktu Oktober sampai November 2015, menunjukan bahwa terdapat 38 perusahaan yang konsesinya terbakar. ${ }^{8}$

Kerugian di bidang kesehatan yang timbul karena pencemaran udara dari karhutla sudah terlihat nyata dan juga cukup meyakinkan: menderita sakit ISPA bahkan hingga kematian. ${ }^{9}$ Indikator yang menentukan bahwa telah terjadi

$5 \quad$ Ibid.

6 Pada periode waktu September sampai Oktober 2015, Indeks Standar Pencemar Udara (ISPU) di kelima Provinsi tersebut berada di atas angka 400. ISPU Provinsi Kalimantan Tengah bahkan mencapai angka 1.987 pada bulan September dan 2.230 pada bulan Oktober. Lihat dalam: Pusdatin Kementerian Kesehatan RI, "Masalah Kesehatan Akibat Kabut Asap Kebakaran Hutan dan Lahan Tahun 2015", http://www.depkes.go.id/resources/ download/pusdatin/infodatin/infodatin-asap.pdf, diakses tanggal 16 Maret 2016.

7 "Ratusan Perusahaan Diduga Terlibat Pembakaran Hutan", http://nasional.republika. co.id/berita/nasional/umum/16/01/22/o1cgje361-ratusan-perusahaan-diduga-terlibatpembakaran-hutan, diakses tanggal 21 Maret 2016.

8 Eyes on the Forest, "Terlibat Kejahatan Kemanusiaan, Para Pelaku Layak Diseret ke Pengadilan", $\quad$ http://eyesontheforest.or.id/attach/Laporan\%20Ringkas\%20EoF\%20 (Dec2015)\%20Pembakaran\%20hutan\%20lahan\%20di\%2037\%20lokasi \%20Riau \%20 FINAL2.pdf, diakses tanggal 21 Maret 2016.

9 Kepala Pusat Data Informasi dan Humas Badan Nasional Penanggulangan Bencana (BNPB), Sutopo Purwo Nugroho, memberikan keterangan bahwa ada 10 korban tewas akibat kabut asap di Sumatera dan Kalimantan, baik lewat dampak langsung maupun tidak langsung. Menurut Sutopo Purwo Nugroho, korban tewas akibat dampak langsung kebakaran hutan dan lahan contohnya adalah korban yang meninggal saat memadamkan api lalu ikut terbakar. Sedangkan korban yang tewas akibat dampak tidak langsung adalah korban yang sakit akibat asap, atau yang sudah punya riwayat sakit lalu adanya asap memperparah sakitnya. Lihat dalam: bbc.com, “Asap Kebakaran Hutan Sampai Jakarta, http://www.bbc.com/indonesia/berita indonesia/2015/10/151024 indonesia_jakarta kabutasap, diakses pada tanggal 21 Juni 2016. 
pencemaran udara akibat asap dari karhutla pun tersedia. Selain itu, informasi mengenai para pihak yang diduga sebagai penyebab terjadinya pencemaran udara dari karhutla pun sudah cukup diketahui. Dengan fakta dan informasi tersebut, ternyata tidak pernah ada gugatan atas dasar pencemaran udara dari karhutla untuk memperoleh kompensasi atas kerugian yang dialami.

Penegakan hukum terhadap peristiwa karhutla dapat dilakukan melalui tiga jalur, yakni melalui jalur pidana, perdata, dan administrasi. Di antara ketiga jalur tersebut, jalur pidana menjadi jalur yang sering digunakan oleh pemerintah dalam penegakan hukum karhutla. ${ }^{10}$ Sementara untuk penegakan hukum perdata dalam kasus karhutla, terdapat beberapa putusan pengadilan yang sudah dihasilkan. ${ }^{11}$ Putusan pengadilan dalam perkara perdata karhutla yang dianggap berhasil adalah putusan Pengadilan Negeri (PN) Meulaboh No. 12/PDT.G/2012/PN.MBO ${ }^{12}$ antara Menteri LHK (Penggugat) melawan PT. Kallista Alam (Tergugat). Gugatan perdata dalam kasus karhutla tersebut merupakan hal yang patut diapresiasi namun sayangnya gugatan ini hanya menyentuh kerusakan lahan yang ditimbulkan

10 Andri G. Wibisana, “Menggugat Kebakaran Hutan", Kompas, Rabu 07 Oktober 2015. Dalam opini tersebut, Andri menyatakan bahwa Polri telah menetapkan 140 tersangka dalam kasus karhutla di tahun 2015.

11 Putusan pengadilan yang sudah dihasilkan dalam perkara perdata karhutla, yakni:

- Putusan PN Meulaboh No. 12.PDT.G/2012/PN.MBO antara Menteri Lingkungan Hidup dan Kehutanan (Menteri LHK) vs PT. Kallista Alam;

- Putusan PN Jakarta Selatan No. 700/Pdt.G/2013/PN.Jkt.Sel. antara Menteri LHK vs PT. Surya Panen Subur. Dalam perkara ini Majelis Hakim menolak seluruh gugatan Penggugat;

- Putusan PN Palembang No. 24/Pdt.G/2015/PN.Plg. antara Menteri LHK vs PT. Bumi Mekar Hijau. Dalam perkara ini Majelis Hakim menolak seluruh gugatan Penggugat; dan

- Putusan PN Jakarta Utara No. 108/Pdt.G/2015/PN.Jkt.Utr, antara Menteri LHK vs PT. Jatim Jaya Perkasa. Dalam perkara ini, Majelis Hakim mengabulkan sebagian gugatan Penggugat.

- Putusan PN Jakarta Selatan No. 591/Pdt.G/2015/PN.Jkt.Sel, antara Menteri LHK vs PT. National Sago Prima. Dalam perkara ini, Majelis Hakim mengabulkan sebagian gugatan Penggugat.

12 Sengketa ini sudah sampai pada tahap kasasi di Mahkamah Agung (MA) dan juga telah diputuskan. MA menolak kasasi yang diajukan oleh PT. Kallista Alam. Lihat: "Kasasi Ditolak, Kalista Alam Harus Bayar Rp 366 Miliar, Menteri Siti: Penuhi Rasa Keadilan", http://www.mongabay.co.id/2015/09/13/kasasi-ditolak-kalista-alam-harus-bayarrp366-miliar-menteri-siti-penuhi-rasa-keadilan/, diakses tanggal 24 Maret 2016. 
dari karhutla. ${ }^{13}$ Pencemaran udara dari karhutla yang menimbulkan kerugian kesehatan pada masyarakat belum pernah dijadikan salah satu bentuk kerugian yang dijadikan tuntutan di dalam gugatan keperdataan.

Jika ditelisik lebih lanjut, gugatan perdata terhadap pencemaran udara yang ditimbulkan dari karhutla memang memiliki tantangan yang lebih berat dibandingkan dengan gugatan perdata terhadap kerusakan lahan yang ditimbulkan dari karhutla. Menurut penulis, terdapat beberapa alasan yang melatarbelakangi-argumen ini: Pertama, pencemaran udara berkaitan dengan material yang intangible - tidak dapat diraba - sehingga membutuhkan usaha yang lebih besar dalam membuktikan bahwa asap dari lahan suatu perusahaan yang mencemari sekelompok orang atau masyarakat; Kedua, terdapat banyak pihak yang berkontribusi terhadap terjadinya pencemaran udara dari karhutla, seperti perusahaan hutan tanaman industri dan perusahaan perkebunan sawit. ${ }^{14}$ Keadaan tersebut menyulitkan korban untuk menentukan pihak mana yang berkontribusi terhadap pencemaran udara dan seberapa besar kontribusinya terhadap pencemaran udara. Ketiga, mobilitas dari material pencemar udara dari karhutla yang cukup luas. Material-material pencemar ini dapat menempuh jarak hingga ratusan kilometer dari sumbernya sehingga sulit bagi para korban untuk meyakinkan Majelis Hakim dalam pengadilan bahwa kerugian yang mereka derita berasal dari pihak-pihak tertentu.

13 Penggugat dalam Menteri LHK vs PT. Kallista Alam mendalilkan beberapa hal yang berkaitan dengan kerugian akibat perbuatan Tergugat. Kerugian tersebut di antaranya meliputi kerugian ekologis (pembuatan dan pemeliharaan reservoir, pengaturan tata air, pembentuk tanah, dll), kerugian hilangnya keanekaragaman hayati dan sumber daya genetika, kerugian akibat terlepasnya karbon ke udara, dan kerugian ekonomis. Keempat jenis kerugian tersebut mayoritas merupakan kerugian atas kerusakan lahan. Memang terdapat kerugian akibat terlepasnya karbon ke udara yang merupakan bentuk pencemaran udara dari karhutla. Namun kerugian ini tidak menyangkut kerugian pencemaran udara yang diderita oleh masyarakat yang terdampak asap dari karhutla. Lihat dalam Menteri LHK vs PT. Kallista Alam, Putusan PN Meulaboh No. 12/PDT.G/2012/PN.MBO, bagian Gugatan, hal. $36-47$.

14 Mas Achmad Santosa mengemukakan pendapat yang serupa perihal sifat-sifat khas dalam kasus pencemaran lingkungan, antara lain: 1). Penyebabnya tidak selalu dari sumber tunggal, akan tetapi berasal dari berbagai sumber (multi sources); 2). Melibatkan disiplindisiplin ilmu lainnya serta menuntut keterlibatan pakar-pakar di luar hukum sebagai saksi ahli; dan 3). Seringkali akibat yang diderita tidak timbul seketika, akan tetapi selang beberapa lama kemudian (long period of latency). Lihat dalam Mas Achmad Santosa, "Teori Pertanggungjawaban Pencemaran (Liability Theories)" dalam Sulaiman N. Sembiring (ed.), Hukum dan Advokasi Lingkungan, (ICEL, 1998), hal. 89. 
Menurut penulis, tantangan tersebut berujung pada tidak adanya gugatan yang dilakukan terhadap pencemaran udara dari karhutla yang diduga terjadi akibat perbuatan, usaha, dan/atau kegiatan dari perusahaan perkebunan dan/ atau kehutanan. Di sisi lain, sebenarnya tantangan tersebut dapat ditelisik lebih lanjut untuk melihat peluang-peluang dilakukannya gugatan pencemaran udara dari karhutla yang merugikan masyarakat terdampak. Tulisan ini akan menelisik peluang-peluang yang dapat dimanfaatkan dalam gugatan pencemaran udara dari karhutla tersebut.

Tulisan ini menggunakan metode penulisan yuridis normatif berdasarkan pada peraturan perundang-undangan yang berlaku di Indonesia sebagai bahan hukum primer. Tulisan ini juga bersumber pada teori dari literatur-literatur hukum dan informasi dari internet yang menjadi bahan hukum sekunder. Tulisan ini akan dibagi ke dalam beberapa bagian.

Setelah bagian Pendahuluan ini, bagian kedua akan membahas mengenai bentuk gugatan tanggung renteng yang dapat diterapkan terhadap peristiwa yang merugikan yang diduga disebabkan oleh perbuatan sekelompok subjek hukum. Lalu pada bagian ketiga akan dibahas perihal joint and several liability yang merupakan bentuk tanggung renteng di dalam sistem hukum common law. Bagian keempat akan membahas peluang dan tantangan gugatan tanggung renteng terhadap peristiwa pencemaran udara dari karhutla. Bagian kelima akan menjadi penutup yang menyimpulkan beberapa hal dari tulisan ini.

\section{Gugatan Tanggung Renteng}

\subsection{Tanggung Renteng dalam Hubungan Perikatan}

Gugatan tanggung renteng merupakan salah satu bentuk gugatan yang dapat digunakan dalam sengketa keperdataan. Dalam hukum perdata Indonesia, gugatan tanggung renteng sebenarnya dilakukan dalam sengketa wanprestasi dalam hubungan hukum perikatan antara lebih dari dua pihak. Hal ini terlihat dalam rumusan Pasal 1278 dan 1280 Kitab Undang-Undang Hukum Perdata (KUHPer) yang menjelaskan pengertian dari tanggung renteng dalam hubungan 
perikatan. ${ }^{15}$ Pasal 1278 KUHper mengatur:

"Suatu perikatan tanggung-menanggung atau perikatan tanggung renteng terjadi antara beberapa kreditur, jika dalam bukti persetujuan secara tegas kepada masing-masing diberikan hak untuk menuntut pemenuhan seluruh utang, sedangkan pembayaran yang dilakukan kepada salah seorang di antara mereka, membebaskan debitur, meskipun perikatan itu menurut sifatnya dapat dipecah dan dibagi antara para kreditur tadi."16

Lalu, Pasal 1280 KUHPer mengatur juga perihal tanggung renteng dengan rumusan: “Di pihak para debitur terjadi suatu perikatan tanggung-menanggung, manakala mereka semua wajib melaksanakan satu hal yang sama, sedemikian rupa sehingga salah satu dapat dituntut untuk seluruhnya, dan pelunasan oleh salah satu dapat membebaskan debitur lainnya terhadap kreditur."17

Berdasarkan pada Pasal 1278 dan 1280 KUHPer, dapat ditarik beberapa kesimpulan mengenai pengertian perikatan tanggung renteng, seperti: ${ }^{18}$ 1) Suatu perikatan dengan lebih dari satu kreditur di satu sisi dengan satu debitur, di sisi lain; atau 2) Suatu perikatan dengan lebih dari satu debitur pada satu sisi dengan satu kreditur pada sisi lain; atau 3) Suatu perikatan dengan lebih dari satu kreditur di satu sisi dan juga dengan lebih dari satu debitur di sisi lain. Pilihan terhadap dua perikatan yang awal memiliki beberapa konsekuensi hukum, di antaranya: ${ }^{19}$

- Dalam hal terdapat lebih dari satu kreditur, masing-masing kreditur berhak untuk menuntut pemenuhan perikatannya dari debitur;

- Dalam hal terdapat lebih dari satu debitur, masing-masing debitur dapat dituntut untuk memenuhi seluruh isi perikatannya oleh kreditur.

- Dalam hal terdapat lebih dari satu kreditur, pemenuhan perikatan kepada salah satu kreditur adalah pemenuhan perikatan kepada semua kreditur; dan

15 Giska Matahari Gegana, Penerapan Prinsip Tanggung Renteng Dalam Hal Kreditur Melakukan Wanprestasi Terhadap Perjanjian Kredit Sindikasi, (Skripsi FHUI, Depok: Juni 2011), hal. 25.

16 Kitab Undang-Undang Hukum Perdata, Pasal 1278, diakses melalui jejaring: http:// hukum.unsrat.ac.id/uu/kolonial_kuh_perdata.pdf.

17 Ibid., Pasal 1280.

18 Giska Matahari Gegana, loc. cit.

19 Ibid., hal. 26. 
- Dalam hal terdapat lebih dari satu debitur, pemenuhan perikatan oleh salah satu debitur adalah pemenuhan perikatan oleh semua debitur.

Dengan pengertian dan konsekuensi hukum dari perikatan tanggung renteng tersebut, maka terdapat dua jenis perikatan tanggung renteng, yaitu: ${ }^{20}$

- $\quad$ Perikatan tanggung renteng yang bersifat aktif, yaitu perikatan dengan lebih dari satu kreditur, di mana masing-masing kreditur berhak untuk menuntut pemenuhan perikatannya dari debitur, dan pemenuhan perikatan kepada salah satu kreditur adalah pemenuhan perikatan kepada semua kreditur; dan

- Perikatan tanggung renteng yang bersifat pasif, yaitu perikatan dengan lebih dari satu debitur, di mana masing-masing debitur dapat dituntut untuk memenuhi seluruh isi perikatannya oleh kreditur, dan pemenuhan perikatan oleh salah satu debitur adalah pemenuhan perikatan oleh semua debitur.

Gugatan tanggung renteng bisa dilakukan ketika terjadi wanprestasi dalam dua jenis perikatan di atas. Sengketa wanprestasi yang menggunakan gugatan tanggung renteng misalnya bisa dilihat dalam sengketa wanprestasi antara PT. Mandira Pelita Utama (Penggugat) melawan PT Hastin International, dkk. (Tergugat). ${ }^{21}$ Dalam kasus tersebut, PT. Mandira Pelita Utama sebagai debitur menggugat secara tanggung renteng tujuh PT yang bertindak sebagai kreditur atas wanprestasi yang dilakukan tujuh PT tersebut terhadap isi perjanjian kredit sindikasi yang telah disepakati bersama. ${ }^{22}$ Majelis Hakim pada tiga tingkat peradilan yang mengadili sengketa tersebut memutuskan bahwa ketujuh Tergugat telah melakukan wanprestasi, lalu membatalkan isi perjanjian kredit sindikasi di antara para pihak dan menghukum para Tergugat untuk membayar kerugian yang diderita oleh Penggugat. ${ }^{23}$

$20 \quad$ Ibid.

21 PT. Mandira Pelita Utama vs PT. Hastin International, et. al., Putusan PN Jakarta Pusat No. 219/Pdt.G/1999/PN.JKT.PST.

22 Giska Matahari Gegana, op. cit., hal. 90

23 Ibid., hal. 92 - 93. Berkaitan dengan gugatan tanggung renteng yang disampaikan oleh Penggugat dalam kasus a quo, Majelis Hakim PN Jakarta Pusat, melalui Putusan No. 219/Pdt.G/1999/PN.JKT.PST, memutuskan bahwa gugatan tanggung renteng terhadap ketujuh Tergugat tidak dapat dikabulkan. Dalam pertimbangannya, Majelis Hakim berpendapat bahwa ganti kerugian harus dibebankan kepada Tergugat sesudai dengan porsi keikutsertaan Para Tergugat dalam perjanjian kredit sindikasi. Lihat dalam: Ibid., hal. 97. Penulis berpendapat bahwa gugatan secara tanggung renteng dilakukan oleh 


\subsection{Tanggung Renteng dalam PMH}

Meskipun dasar hukumnya hanya mengatur gugatan terhadap tindakan wanprestasi, gugatan tanggung renteng dipraktikan juga dalam gugatan perbuatan melawan hukum. Dua contoh sengketa perdata yang menggunakan gugatan tanggung renteng di antaranya:

- $\quad$ Dedi, dkk. vs PT. Perhutani, dkk., yang diperiksa di PN Bandung, ${ }^{24}$ mengenai longsornya Hutan Mandalawangi akibat kegiatan kehutanan dari PT. Perhutani (kasus ini dikenal dengan istilah "Mandalawangi"); dan

- Aswardi, dkk. vs PT. Cahaya Bintan Abadi, dkk., yang diperiksa di PN Tanjung Pinang, ${ }^{25}$ tentang pencemaran lingkungan laut akibat pertambangan dan penimbunan tanah merah untuk pembangunan dermaga.

Jika kita menelisik dalil-dalil mengenai gugatan tanggung renteng di dalam dua putusan di atas, kita dapat melihat bahwa baik Penggugat maupun Majelis Hakim tidak mendasarkan pada dasar hukum tertulis dalam mendalilkan atau mempertimbangkan gugatan tanggung renteng. Dalam sengketa antara Aswardi, dkk. vs PT. Cahaya Bintan Abadi, dkk. misalnya, para Penggugat dalam gugatannya mendalilkan perihal tanggung renteng dalam posita mengenai jumlah kerugian materiil dan immateriil yang diderita akibat perbuatan melawan hukum yang dilakukan oleh Tergugat I, Tergugat II, dan Tergugat III. ${ }^{26}$ Para Penggugat kembali mendalilkan perihal tanggung renteng dalam bagian petitum gugatannya, yakni memohon Majelis Hakim untuk menghukum dan memerintahkan Tergugat I, Tergugat II, dan Tergugat III secara tanggung renteng membayar ganti rugi kepada para Penggugat sebesar Rp 100.057.600.000. ${ }^{27}$ Penggugat tidak mendasarkan pada

Penggugat dengan tujuan memperoleh jaminan bahwa keseluruhan kerugian yang diderita oleh Penggugat dapat dibayar oleh salah satu Tergugat atau lebih. Selain itu, gugatan dilakukan secara tanggung renteng juga agar gugatan bisa lebih efisien dibandingkan dengan menggugat masing-masing Tergugat secara terpisah.

24 Dedi, dkk. vs PT. Perhutani, dkk. Putusan PN Bandung No. 49/Pdt.G/2003/PN.BDG.

25 Aswardi, dkk. vs PT. Cahaya Bintan Abadi, dkk. Putusan PN Tanjung Pinang No. 26/ PDT.G/2009/PN.TPI,

26 Ibid., Bagian posita gugatan, hal. 15.

27 Ibid., hal. 23. Majelis Hakim dalam putusannya mengabulkan sebagian gugatan dari para 
dasar hukum tertulis dalam merumuskan dalil gugatan tanggung renteng, baik itu dalam posita atau pun petitum-nya.

Terdapat sedikit perbedaan di dalam perkara "Mandalawangi" perihal perumusan gugatan tanggung renteng. Di dalam perkara "Mandalawangi", para Penggugat tidak mendalilkan secara eksplisit bentuk tanggung renteng di dalam surat gugatannya. ${ }^{28}$ Namun Majelis Hakim perkara "Mandalawangi" di dalam pertimbangannya terhadap petitum Penggugat, menyatakan bahwa biaya pemulihan kerusakan hutan di Gunung Mandalawangi harus ditanggung oleh Tergugat I (PT. Perhutani) dan Tergugat III (Menteri Kehutanan) secara tanggung renteng. ${ }^{29}$ Majelis Hakim perkara "Mandalawangi" juga memutuskan bahwa Tergugat I, Tergugat III, Tergugat IV (Gubernur Jawa Barat), dan Tergugat V (Bupati Garut) secara tanggung renteng membayar ganti kerugian kepada korban longsor Gunung Mandalawangi sebesar Rp 10.000.000.000,-. ${ }^{30}$ Majelis Hakim perkara "Mandalawangi" tidak mendasarkan pada dasar hukum tertulis dalam pertimbangan tersebut, melainkan mendasarkan pada rasa keadilan dan kepatutan. ${ }^{31}$

Dari kedua sengketa tersebut dapat dilihat bahwa gugatan tanggung renteng atas perbuatan melawan hukum dilakukan tidak berdasarkan pada suatu dasar hukum tertentu. Dalam perkara antara Aswardi, dkk. vs PT. Cahaya Bintan Abadi, dkk., pihak Penggugat merumuskan dalil tanggung renteng dalam posita dan petitum-nya tanpa didasarkan pada suatu dasar hukum tertentu. Dalam perkara "Mandalawangi", Majelis Hakim PN Bandung mendasarkan pada rasa keadilan dan kepatutan dalam mempertimbangkan pemulihan dan ganti rugi secara tanggung renteng oleh beberapa Tergugat. Dengan kata lain, perihal tanggung renteng dalam PMH didasarkan pada kebiasaan serta rasa keadilan dan kepatutan.

Penggugat, salah satunya dalam hal ganti rugi, yakni menghukum Tergugat I, II, dan III secara tanggung renteng membayar ganti rugi kepada para Penggugat sebesar Rp 10.760.000.000. Lihat: Ibid., hal, 128 - 129.

28 Perumusan dalil tanggung renteng di dalam petitum seperti yang terlihat dalam perkara Aswardi, dkk. vs PT. Cahaya Bintan Abadi, dkk. tidak terlihat di dalam gugatan Dedi, dkk. dalam perkaranya melawan PT. Perhutani, dkk. Lihat dalam: Dedi, dkk. vs PT Perhutani, dkk.. Putusan PN Bandung No. 49/Pdt.G/2003/PN.BDG., Bagian Petitum, hal. 10 - 12.

29 Ibid., hal. 104 dan $108 .$.

30 Ibid.

31 Ibid., hal. 104. 


\subsection{Para Pihak dalam Gugatan Tanggung Renteng}

Hal yang perlu dicermati dalam gugatan tanggung renteng adalah pihakpihak yang dapat dijadikan Tergugat di dalam sengketa. Terdapat perbedaan antara pihak-pihak yang dapat dijadikan Tergugat dalam gugatan tanggung renteng pada sengketa wanprestasi dan PMH. Dalam gugatan tanggung renteng pada sengketa wanprestasi, pihak-pihak yang dapat dijadikan Tergugat berkaitan erat dengan para pihak yang mengadakan perjanjian. Dengan kata lain, pihak yang merasa dirugikan atas wanprestasi dalam perjanjian tanggung renteng harus menyertakan seluruh pihak yang terikat kepada perjanjian tanggung renteng tersebut. ${ }^{32}$

Disertakannya seluruh pihak dalam gugatan tanggung renteng pada sengketa wanprestasi merupakan hal yang krusial karena adanya kemungkinan gugatan dinyatakan niet ontvankelijke verklaard (NO) atau tidak dapat diterima oleh Majelis Hakim apabila gugatan dinilai kurang pihak. Hal ini berdasarkan pada logika bahwa pihak Penggugat, dalam sengketa wanprestasi, mengetahui pihak mana saja yang merupakan penyebab terjadinya kerugian yang ia derita. Selain itu, gugatan tanggung renteng dalam sengketa wanprestasi memang harus didasarkan pada perikatan yang sah di antara para pihak, di mana pilihan dilakukannya gugatan tanggung renteng juga harus dinyatakan dengan tegas di dalam perikatan tersebut.

Berbeda dengan sengketa wanprestasi, dalam gugatan tanggung renteng pada PMH Penggugat tidak dibatasi dengan keharusan melakukan gugatan dengan jumlah Tergugat yang sudah pasti atau lengkap. Hal ini dikarenakan gugatan PMH tidak didasari pada perikatan di antara para pihak, melainkan pada ketentuan-ketentuan hukum yang hidup di dalam masyarakat. ${ }^{33}$ Selain itu, pihak yang merasa dirugikan dalam sengketa $\mathrm{PMH}$ biasanya berada dalam keadaan minim informasi mengenai pihak mana yang telah menyebabkan kerugian yang ia derita, terlebih lagi dalam sengketa dengan multipihak di dalamnya. Maka dari

32 Misalnya dalam sengketa wanprestasi atas perjanjian kredit sindkasi antara PT. Mandira Pelita Utama vs PT. Hastin International Bank, dkk., pihak PT. Mandira Pelita Utama yang merasa dirugikan atas wanprestasi yang dilakukan oleh PT. Hastin International Bank, dkk. harus menyertakan seluruh pihak yang terikat pada perjanjian kredit sindikasi tersebut.

33 Dasar gugatan PMH, selain berdasarkan pada ketentuan hukum tertulis, dapat juga di antaranya dilakukan berdasarkan pada nilai-nilai kepatutan, kehati-hatian, dan ketelitian yang hidup di dalam masyarakat. Lihat dalam: Rosa Agustina, Perbuatan Melawan Hukum, (Jakarta: Pascasarjana FHUI, 2003), hal. 4-8. 
itu, gugatan tanggung renteng pada sengketa $\mathrm{PMH}$ tidak mengharuskan seorang Penggugat untuk tahu dengan pasti pihak mana saja yang telah menyebabkan kerugian yang ia derita.

\section{Perbandingan Tanggung Renteng dengan Joint and Several Liability}

Gugatan tanggung renteng di dalam sistem hukum common law dikenal dengan istilah joint and several liability. Applegate dan Laitos berpendapat, sebagaimana dikutip oleh Wibisana, bahwa makna dari joint and several liability adalah, " the entire burden can be shifted to any contributor to the harm, even one that has only a tiny role, leaving to that party the task of seeking contribution from other defendants, if possible". ${ }^{34}$ Berdasarkan makna tersebut, Wibisana berpendapat bahwa dalam joint and several liability, Penggugat pada pokoknya meminta para Tergugat secara bersama-sama membayar ganti rugi atas kerugian yang ia derita. ${ }^{35}$ Tergugat mana di antara para Tergugat yang akan membayar kerugian yang diderita oleh Penggugat sepenuhnya diserahkan kepada kesepakatan para Tergugat. Apakah ganti rugi tersebut akan seluruhnya ditanggung oleh seorang Tergugat, atau akan dibagi rata berdasarkan proporsi tertentu menjadi urusan para Tergugat. ${ }^{36}$ Dengan kata lain, Penggugat tidak perlu membuktikan proporsi/kontribusi dari tiap Tergugat atas kerugian yang diderita Penggugat. ${ }^{37}$

Perihal penerapan dari joint and several liability, ulasan dari The Law Commission of New Zealand dapat dijadikan sebagai acuan. Menurut ulasan tersebut, aturan joint and several liability berkaitan dengan dua isu utama, yakni: ${ }^{38}$ Pertama, karakteristik dari kerugian. Apakah tindakan atau kelalaian dari para Tergugat menimbulkan suatu kerugian yang tak dapat dipisahkan atau kerugian tersebut terpisah atau dapat dipisahkan. Kedua karakteristik kerugian tersebut menentukan apakah joint

34 Andri Gunawan Wibisana, Pertanggungjawaban Perdata dan Pembuktian Dalam Hukum Lingkungan Indonesia, (Makalah disampaikan dalam lokakarya kebakaran hutan dan lahan Walhi, Oktober 2015), hal. 35.

35 Ibid.

36 Ibid.

37 Ibid.

38 Law Commission of New Zealand, "Review of Joint and Several Liability", November 2012, Wellington, New Zealand, Issues Paper 32, hal. 10. 
and several liability dapat diterapkan atau tidak; kedua, perihal pembagian beban pertanggungjawaban di antara para Tergugat.

Pada isu mengenai karakteristik kerugian, hanya ketika seluruh kerugian yang diderita Penggugat memiliki karakter yang sama, atau tindakan dari masingmasing Tergugat seluruhnya berkontribusi pada keseluruhan kerugian, maka joint and several liability dapat diterapkan. ${ }^{39}$ Ketika kondisi tersebut terpenuhi dan salah satu Tergugat tidak mampu melakukan ganti rugi, Tergugat lainnya akan secara bersama-sama membayar keseluruhan ganti rugi. ${ }^{40}$

Lalu pada isu yang kedua, yakni perihal pembagian beban pertanggungjawaban, menurut hukum yang berlaku di New Zealand, ${ }^{41}$ pembagian beban pertanggungjawaban bukanlah beban dari Penggugat. ${ }^{42}$ Jika seorang Penggugat hanya menggugat terhadap satu Tergugat saja dan Tergugat tersebut berpendapat bahwa terdapat pihak-pihak lainnya yang seharusnya bertanggung jawab juga, Tergugat tersebut dapat mengikutsertakan para pihak-pihak yang dianggap ikut bertanggung jawab ke dalam proses persidangan atau membuat klaim kontribusi dari pihak-pihak lain secara terpisah setelah adanya putusan terhadap gugatan yang disampaikan oleh Penggugat. ${ }^{43}$ Penggugat harus membuktikan bahwa Tergugat yang dipilih untuk digugat merupakan penyebab terjadinya kerugian yang ia derita, akan tetapi Penggugat tidak diwajibkan untuk menelusuri kontribusi atau kesalahan masing-masing Tergugat dibandingkan dengan pihak-pihak lain yang berpotensi menjadi Tergugat. Dengan kata lain, Penggugat dapat memilih untuk menggugat hanya satu Tergugat saja dan menyerahkan pada Tergugat tersebut untuk memutuskan apakah Tergugat akan mencari pihak lain yang berkontribusi juga pada kerugian Penggugat. ${ }^{44}$

Aturanjoint and several liability melindungi Penggugat dengan mengatur bahwa masing-masing pihak yang telah menyebabkan terjadinya kerugian bertanggung

39 Ibid. hal. 11.

40 Ibid.

41 Perlu dicatat bahwa aturan perihal pembagian beban pertanggungjawaban yang dimaksud dalam kalimat ini berlaku pada tahun 2012, ketika ulasan ini dilakukan oleh The Law Commission of New Zealand.

42 Ibid.

43 Ibid.

44 Ibid. 
jawab untuk membayar secara penuh kerugian Penggugat. ${ }^{45}$ Jika Penggugat tidak dapat mendapatkan ganti rugi dari satu Tergugat, Penggugat dapat memperoleh ganti rugi secara penuh dari Tergugat lainnya. Prinsip dasar dari aturan ini adalah pendekatan common law terhadap kausalitas, yakni: masing-masing Tergugat telah menyebabkan terjadinya kerugian yang tak dapat dipisahkan yang diderita oleh Penggugat, maka masing-masing Tergugat harus bertanggung jawab terhadap kerugian tersebut. Dalam sistem hukum common law, pihak yang menderita kerugian tidak seharusnya menanggung risiko tidak adanya Tergugat atau ketidaksanggupan Tergugat untuk membayar ganti rugi. Sebaliknya, pengadilan dalam sistem hukum common law mengalokasikan risiko tersebut kepada para pihak yang dinilai telah menyebabkan kerugian pada Penggugat. ${ }^{46}$

\subsection{Joint and Several Liability dalam Putusan Pengadilan di Amerika Serikat}

Terdapat dua putusan pengadilan yang cukup terkenal di Amerika Serikat yang menerapkan joint and several liability dalam perkara PMH. Dua perkara tersebut adalah: 1). United States v. Chem-Dyne Corp; dan 2). O'Neil v. Picillo. Penulis akan mengulas hal-hal penting berkaitan dengan joint and several liability di dalam dua perkara tersebut.

\section{a. United States v. Chem-Dyne Corp.}

Perkara United States v. Chem-Dyne Corp merupakan perkara antara Pemerintah Federal Amerika Serikat melawan sekelompok perusahaan yang membuang limbah bahan beracun dan berbahaya (B3) ke dalam fasilitas yang dimiliki oleh Chem-Dyne Corp. ${ }^{47}$ Di dalam perkara tersebut, pemerintah federal Amerika Serikat menggugat sekelompok perusahaan tersebut secara tanggung renteng untuk membayar biaya yang telah dikeluarkan oleh pemerintah untuk melakukan penanggulangan dan pemulihan pencemaran limbah B3. Di sisi lain, para Tergugat di dalam perkara tersebut memohon kepada Majelis Hakim untuk memutus bahwa para Tergugat tidak bertanggung jawab secara

45 Ibid.

46 Ibid.

47 Perkara ini diadili di United States District Court, Southern District of Ohio pada tahun 1983. Lihat: Jeffrey G. Miller dan Craig N. Johnson, $2^{\text {nd }}$ Edition, The Law of Hazardous Waste Disposal and Remediation: Cases-Legislation-Regulation-Policies, (St. Paul: Thomson West, 2005), hal. 584. 
tanggung renteng terhadap biaya pemulihan Chem-Dyne. ${ }^{48}$

Dalam perkara tersebut, Pemerintah Federal Amerika Serikat menegaskan bahwa perumusan mengenai joint and several liability sudah cukup jelas tergambar di dalam bahasa pengaturan Comprehensive Environmental Response, Compensation, and Liability Act (CERCLA). Akan tetapi, Majelis Hakim Southern District of Ohio menilai bahwa rumusan pasal mengenai ruang lingkup pertanggungjawaban di dalam CERCLA bersifat ambigu. ${ }^{49}$ Dengan keadaan tersebut, Majelis Hakim mencoba melihat maksud dari pembentuk CERCLA dengan mengkaji ulang proses legislasi dari CERCLA. ${ }^{50}$

Berdasarkan hasil kaji ulang terhadap proses legislasi dari CERCLA, Majelis Hakim mengidentifikasi alasan dihapuskannya terminologi strict liability dan joint and several liability dalam CERCLA pada tanggal 24 November 1980. Alasan penghapusan kedua terminologi tersebut di dalam CERCLA didalilkan juga oleh Chem-Dyne Corp. melalui pernyataan Senator Helms, yakni: ${ }^{51}$

"Retention of joint and several liability in S. 1480 received intense and well-deserved criticism from a number of sources, since it could impose financial responsibility for massive costs and damages awards on person who contributed only minimally (if at all) to a release or injury. Joint and several liability for costs and damages was especially pernicious in S. 1480, not only because of the exceedingly broad categories of persons subject to liability and the wide array of damages available, but also because it was coupled with an industrybased fund. Those contributing to the fund will frequently be paying for conditions they had no responsibility in creating or even contributing to.

To adopt a joint and several liability scheme on top of this would have been grossly unfair.

The drafters of the Stafford Randolph substitute have recognized this unfairness, and the lack of wisdom in eliminating any meaningful

$\begin{array}{ll}48 & \text { Ibid. } \\ 49 & \text { Ibid. } \\ 50 & \text { Ibid. } \\ 51 & \text { Ibid., hal. } 584-585 .\end{array}$


link between culpable conduct and financial responsibility. Consequently, all references to joint and several liability in the bill have been deleted...

It is very clear from the language of the Stafford Randolph substitute itself, from the legislative history, and from the liability provisions of section 311 of Federal Water Pollution Control Act, that now the Stafford Randolph bill does not in and of itself create joint and several liability. ${ }^{\prime 52}$ (penebalan berasal dari penulis)

Di sisi lain Majelis Hakim dalam perkara United States v. Chem-Dyne Corp. juga mengutip pernyataan Senator Stafford Randolph yang menjelaskan alasan di balik penghapusan terminologi joint and several liability. Pernyataan Senator Stafford Randolph ini akan menunjukan bagaimana seharusnya joint and several liability diterapkan dalam perkara-perkara dengan pihak Tergugat yang jumlahnya lebih dari satu. Berikut ini pernyataan Senator Stafford Randolph: ${ }^{53}$

"We have kept strict liability in the compromise, specifying the standard of liability under section of 311 of the Clean Water Act, but we have deleted any reference to joint and several liability, relying on common law principles to determine when parties should be severally liable... the changes were made in recognition of the difficulty in prescribing in statutory terms liability standards which will be applicable in individual cases. The changes do not reflect a rejection of the standards in the earlier bill. It is intended that issues of liability not resolved by this act, if any, shall be governed by traditional and evolving principles of common law. An example is joint and several liability. Any reference to these terms has been deleted, and the liability of joint tortfeasors will be

52 Pandangan Senator Helms mengenai perumusan terminologi joint and several liability dalam CERCLA bertentangan dengan panduan yang dibuat oleh Mahkamah Agung Amerika Serikat. Senator Helms merupakan pihak yang menentang disusunnya CERCLA. Maka dari itu, pernyataan Senator Helms ditujukan untuk memperkecil ruang penafsiran dari CERCLA. Lihat: Ibid., hal. 585. 
determined under common or previous statutory law." 54 (penebalan berasal dari penulis).

Berdasarkan paparan dari Senator Stafford Randolph tersebut, kita dapat melihat bahwa dihapuskannya perihal scope of liability dan joint and several liability dalam CERCLA dilakukan untuk menghindari adanya suatu standar yang dapat diterapkan dalam semua situasi, yang mana dapat menghasilkan putusan yang tidak adil dalam beberapa kasus tertentu. ${ }^{55} \mathrm{Akan}$ tetapi penghapusan tersebut tidak dimaksudkan sebagai penolakan terhadap joint and several liability. Sebetulnya, terminologi joint and several liability dihapuskan agar scope of liability dapat ditentukan dengan mengacu pada prinsip-prinsip common law, di mana pengadilan akan menilai kelayakan penerapan joint and several liability berdasarkan pada basis individual dari sekian jumlah Tergugat. ${ }^{56}$

Pertimbangan Majelis Hakim yang menyatakan bahwa joint and several liability diterapkan dengan mengacu pada prinsip-prinsip common law juga memunculkan dua isu lainnya. Isu yang pertama adalah menentukan state common law atau federal common law yang seharusnya diterapkan dalam perkara a quo. Isu yang kedua adalah menentukan apakah interpretasi lingkup pertanggungjawaban dilakukan berdasarkan pada gabungan state law dari beberapa Negara bagian atau berdasarkan pada "a federally created uniform law".

Dalam menjawab isu pertama, Majelis Hakim mempertimbangkan adanya Erie Doctrine. Erie Doctrine menyatakan bahwa federal court harus menerapkan state substantive law dalam perkara-perkara yang melintasi lebih dari satu jurisdiksi. ${ }^{57}$ Akan tetapi, Majelis Hakim berpendapat bahwa state law tidak wajib diterapkan di dalam perkara United States v. Chem-Dyne Corp. karena karakteristik perkara tersebut termasuk ke dalam makna dari

54 Senator Stafford Randolph merupakan pihak yang mendukung penyusunan CERCLA. Majelis Hakim juga mengutip pernyataan dari Representatives Florio and Waxman yang isinya serupa dengan pernyataan dari Senator Stafford Randolph. Lihat: Ibid.

55 Ibid., hal. 586.

56 Ibid.

57 Penjelasan lebih lanjut mengenai Erie Doctrine dapat dilihat di dalam: http://civilprocedure. uslegal.com/choice-of-law/erie-doctrine/ (diakses pada 31 Juli 2016). 
"uniquely federal interest. ${ }^{58}$ Sebaliknya, karena adanya uniquely federal interest dalam perkara a quo, Majelis Hakim menyimpulkan bahwa perihal hak dan pertanggungjawaban dari United States di dalam Pasal 107 CERCLA ditentukan berdasarkan pada "federal rule of decision". ${ }^{59}$

Isu yang kedua adalah menentukan apakah interpretasi lingkup pertanggungjawaban dilakukan berdasarkan pada gabungan state law dari beberapa Negara bagian atau berdasarkan pada "a federally created uniform law". Menurut Majelis Hakim, penentuan interpretasi lingkup pertanggungjawaban merupakan kebijakan yudisial yang bergantung pada bermacam-macam pertimbangan. ${ }^{60}$ Pertimbangan tersebut berkaitan dengan esensi dari kepentingan-kepentingan spesifik suatu pemerintahan dan bagaimana efeknya terhadap mereka yang menerapkan state law. ${ }^{61}$ Programprogram Pemerintah Federal Amerika Serikat yang pada esensinya harus seragam dalam karakternya di seluruh Negara bagian di Amerika Serikat, mengharuskan adanya perumusan "federal rules of decision". CERCLA merupakan contoh dari program Pemerintah Federal Amerika Serikat. Standar pertanggungjawaban yang bervariasi di setiap forum Negara bagian akan melemahkan kebijakan-kebijakan dalam CERCLA dengan mendorong

58 Erie Doctrine telah mengeliminasi kekuasaan federal courts untuk menciptakan federal general common law. Akan tetapi kekuasaan untuk membuat federal specialized common law tetap tidak tersentuh ketika kekuasaan tersebut diperlukan untuk melindungi "uniquely federal interest". Lihat dalam Jeffrey G. Miller dan Craig N. Johnson, op. cit., hal. 586.

59 Terdapat dua alasan yang melatarbelakangi diterapkannya "federal rule of decision" dalam perkara United States v. Chem-Dyne Corp. Pertama, pembuangan bahan-bahan beracun dan berbahaya (B3) merupakan permasalahan nasional yang besar dan kompleks. Biasanya, tempat buangan limbah yang tidak diperhatikan akan terdiri dari limbah yang dihasilkan oleh bermacam-macam perusahaan dari Negara-negara bagian yang berbeda dalam suatu area atau region. Terjadinya pencemaran pada tanah, air tanah, dan air permukaan sebagai konsekuensi dari pembuangan limbah tersebut menghasilkan permasalahan lintas Negara bagian. Kedua, alasan yang melatarbelakangi penyusunan CERCLA adalah pengakuan bahwa respon terhadap permasalahan yang dapat meluas ini pada tingkatan Negara Bagian dirasa masih tidak memadai. Terlebih lagi, dana Superfund yang digunakan untuk melakukan pemulihan berasal dari "general revenues" dan "excise taxes". Maka dari itu, tingkatan bagi pemerintah federal Amerika Serikat untuk dapat melindungi kepentingan finansialnya di dalam "trust fund" berhubungan secara langsung pada lingkup pertanggungjawaban berdasarkan CERCLA dan tidak mungkin bergantung pada aturan hukum dari Negara bagian. (penebalan berasal dari penulis). Lihat penjelasan ini dalam: Ibid.

60 Ibid., hal. 587.

61 Ibid 
dilakukannya pembuangan limbah yang illegal di Negara bagian dengan aturan hukum pertanggungjawaban yang lebih longgar. Maka dari itu, interpretasi lingkup pertanggungjawaban ditentukan dengan didasarkan pada "a federally created uniform law". ${ }^{62}$

Setelah melihat pertimbangan Majelis Hakim bahwa federal common law yang digunakan dalam memeriksa perkara United States v. Chem-Dyne Corp., maka langkah terakhir yang diperlukan adalah melihat bagaimana federal common law menginterpretasikan joint and several liability. Penelusuran terhadap common law menunjukan bahwa ketika dua pihak atau lebih melakukan perbuatan secara independen yang menyebabkan suatu kerugian tunggal atau kerugian yang dapat dibedakan, yang mana terdapat dasar yang wajar untuk melakukan pembagian berdasarkan kontribusi dari masingmasing pihak, maka masing-masing pihak tersebut bertanggung jawab hanya terhadap sebagian dari total kerugian yang disebabkan oleh perbuatannya. ${ }^{63}$ Tetapi, ketika dua pihak atau lebih menyebabkan terjadinya kerugian tunggal dan kerugian tersebut tidak dapat dibagi-bagi, masing-masing pihak tersebut bertanggung jawab untuk keseluruhan kerugian. ${ }^{64}$ Lebih jauh lagi, ketika perbuatan dua atau lebih pihak telah melanggar ketentuan di dalam Pasal 107 CERCLA, dan salah satu Tergugat atau lebih meminta adanya pembatasan pertanggungjawaban dengan alasan bahwa keseluruhan kerugian dapat dilakukan pembagian, beban pembuktian terhadap pembagian kerugian tersebut ada pada masing-masing Tergugat. ${ }^{65}$

Pada akhirnya, upaya menentukan apakah para Tergugat dalam perkara United States $v$. Chem-Dyne Corp. bertanggung jawab secara bersamasama (jointly) atau secara terpisah (severally) atas biaya pemulihan menjadi

62 CERCLA mengatur hak bagi Pemerintah Federal Amerika Serikat untuk melakukan reimbursement atas biaya yang dikeluarkan untuk pemulihan suatu area yang tercemar. Hak tersebut dibutuhkan untuk penanganan permasalahan pencemaran secara nasional yang seragam. Maka dari itu, hak untuk memeroleh reimbursement tersebut sebaiknya tidak dihadapkan dengan ketidakpastian aturan-aturan lokal dari Negara-negara bagian yang variatif. Lihat dalam: Ibid.

63 Ibid.

64 Ibid.

65 Ibid. 
pembuktian faktual yang cukup kompleks. ${ }^{66}$ Chem-Dyne menampung bermacam-macam limbah B3 yang berasal dari 289 penghasil atau pengangkut limbah yang berat totalnya mencapai sekitar 608.000 pon. Beberapa limbah B3 tersebut telah bercampur tetapi sumbernya masih tidak dapat dipastikan. Fakta bahwa limbah B3 tersebut bercampur telah menaikkan isu mengenai dapat atau tidaknya kerugian dipisah-pisahkan berdasarkan pihak yang menyebabkan terjadinya kerugian tersebut. ${ }^{67}$ Lebih jauh lagi, perdebatan juga terjadi mengenai limbah B3 mana yang telah mencemari air tanah, juga mengenai tingkat migrasi limbah B3, serta bahaya pada kesehatan yang dapat ditimbulkan dari limbah B3 tersebut. ${ }^{68}$ Selain itu, upaya memperkirakan resiko yang terkandung dalam suatu limbah dengan mendasarkan pada volume limbah yang dibuang oleh penghasil limbah bukanlah langkah yang tepat. Hal ini dikarenakan potensi racun dan migrasi dari suatu limbah B3 tertentu secara umum bervariasi dan tidak tergantung pada volume dari limbahnya. ${ }^{69}$

Karena adanya isu-isu fakta material mengenai dapat atau tidaknya kerugian dipisahkan berdasarkan pihak yang menyebabkan kerugian serta mengenai dapat atau tidaknya dilakukan pembagian beban pertanggungjawaban, permohonan Tergugat (Che-Dyne Corp.) kepada Majelis Hakim untuk diputuskannya "judgment as a matter of law" ${ }^{\text {"70 }}$ ditolak. ${ }^{71}$

\section{b. O’Neil v. Picillo}

O’Neill v Picillo merupakan perkara pencemaran limbah B3 yang terjadi di Coventry, Rhode Island, Amerika Serikat. Pencemaran limbah B3 ini bermula ketika Picillo sepakat untuk memperbolehkan sebagian dari peternakan babi

66 Ibid.

67 Ibid., hal. 588.

68 Ibid.

69 Ibid.

70 Judgment as a matter of law adalah permohonan yang diajukan oleh salah satu pihak dalam perkara di pengadilan sebelum kasus diserahkan kepada Juri. Salah satu pihak tersebut mengajukan permohonan kepada Majelis Hakim untuk menjatuhkan putusan yang menguntungkan pihak tersebut dengan alasan tidak cukupnya bukti awal yang ditunjukan oleh pihak lain kepada juri. Judgment as a matter of law dikenal juga dengan istilah directed verdict. Lihat dalam: "Motion for Judgment as a Matter of Law", https://www.law.cornell. edu/wex/motion_for_judgment_as_a_matter_of_law, diakses pada 31 Juli 2016.

71 Jeffrey G. Miller dan Craig N. Johnson, loc. cit. 
miliknya digunakan sebagai tempat pembuangan limbah B3 dalam jumlah yang besar. ${ }^{72}$ Ribuan barel limbah B3 yang dibuang di dekat peternakan Picillo pada akhirnya menimbulkan terjadinya kebakaran dikarenakan penyimpanan limbah B3 yang ceroboh. Pada tahun 1979, The State of Rhode Island dan Environmental Protection Agency (EPA) melaksanakan pemulihan pencemaran limbah B3 di lokasi tersebut. ${ }^{73}$

The State of Rhode Island menggugat 35 perusahaan untuk membayar biaya pemulihan yang sudah dikeluarkan di antara tahun 1979 sampai 1982 dan juga meminta 35 perusahaan tersebut bertanggung jawab untuk seluruh biaya di masa depan yang dikeluarkan berkaitan dengan tempat tercemar limbah B3 tersebut. ${ }^{74} 30$ perusahaan dari total 35 perusahaan tersebut pada awal persidangan di pengadilan tingkat pertama bersepakat untuk melakukan pembayaran sebesar $\$ 5.800 .000$ yang akan dibagikan kepada The State of Rhode Island dan EPA. ${ }^{75}$ Pengadilan tingkat pertama pada akhirnya memutuskan bahwa tiga dari lima perusahaan lainnya bertanggung jawab secara tanggung renteng (joint and several liability) atas seluruh biaya pemulihan terdahulu yang tidak tercakup di dalam kesepakatan pembayaran (oleh 30 perusahaan) serta turut bertanggung jawab juga untuk biaya pemulihan di masa depan. ${ }^{76}$ Dua dari tiga perusahaan yang diputuskan bertanggung jawab di pengadilan tingkat pertama, American Cyanamid dan Rohm and Haas, melakukan banding terhadap putusan tersebut. ${ }^{77}$

American Cyanamid dan Rohm and Haas (para Pembanding) mengajukan banding berdasarkan dua alasan. Pada alasan yang pertama, para Pembanding menyatakan bahwa kontribusi keduanya terhadap pencemaran tidak signifikan sehingga tidaklah adil untuk memutuskan kedua perusahaan

72 Ibid.

73 Berdasarkan keterangan di District Court (pengadilan tingkat pertama), The State of Rhode Island dan EPA pada saat melakukan pemulihan pencemaran menemukan banyak parit dan lubang berukuran besar. Parit dan lubang besar tersebut dipenuhi oleh "free-flowing, multicolored, pungent liquid wastes" dan ribuan "dented and corroded drums containing a veritable potpourri of toxic fluids". Lihat dalam: Ibid.

74 Ibid.

75 Ibid.

76 Ibid.

77 Ibid. 
tersebut bertanggung jawab secara tanggung renteng atas pengeluaran State of Rhode Island yang tidak tercakup di dalam kesepakatan pembayaran oleh 30 perusahaan lainnya. ${ }^{78}$ Para Pembanding mendalilkan bahwa sebelum joint and several liability dapat dijatuhkan, pihak Pemerintah memiliki beban untuk membuktikan bahwa para pembanding merupakan penyebab "substansial" terjadinya kerugian. ${ }^{79}$ Jika pemerintah tidak dapat membuktikan bahwa para Pembanding merupakan kontributor "substansial", maka joint and several liability tidak dapat dijatuhkan dan beban para Pembanding untuk membuktikan bahwa kerugian dapat dipisahkan menjadi hilang. ${ }^{80}$

Majelis Hakim di pengadilan tingkat banding menolak dalil para Pembanding tersebut. Majelis Hakim menolak untuk menempatkan beban kepada Pemerintah untuk membuktikan bahwa para Pembanding merupakan kontributor "substansial" dalam gugatan joint and several liability. ${ }^{81}$ Majelis Hakim mencermati bahwa beberapa putusan pengadilan juga telah menolak menempatkan beban kepada pemerintah untuk membuktikan bahwa para Tergugat merupakan kontributor "substansial" terjadinya kerugian. ${ }^{82}$ Beberapa putusan pengadilan tersebut menyadari pertimbangan Congress yang menyatakan bahwa upaya pemulihan jangan sampai tersandera oleh kewajiban yang memakan waktu lama dan juga hampir mustahil dilakukan, yakni: menelusuri sumber seluruh limbah yang ditemukan di tempat pembuangan limbah. ${ }^{83}$

Majelis Hakim pengadilan tingkat banding lalu kembali mendasarkan pada aturan yang ada di dalam Restatement (Second) of Torts, yakni: kerugian harus dibagi hanya jika para Tergugat dapat membuktikan bahwa kerugian dapat dipisahkan. ${ }^{84}$ Aturan ini pun menjadi dasar bagi alasan banding para Pembanding yang kedua, yakni: para Pembanding telah berhasil membuktikan

$78 \quad$ Ibid.

79 Para Tergugat mengacu pada Restatement (Second) of Torts 433B. Ibid., hal. 589.

80 Ibid.

81 Ibid.

82 Ibid., hal. 590.

83 Ibid.

84 Ibid., hal. 589. 
bahwa kerugian dalam perkara ini dapat dipisahkan. ${ }^{85}$

Para Pembanding berpendapat, karena merupakan hal yang mungkin untuk menentukan jumlah barel limbah yang mereka buang ke tempat pembuangan, maka dimungkinkan pula untuk menentukan berapa proporsi dari biaya pemulihan yang dikeluarkan oleh pemerintah yang dapat dibebankan kepada para Pembanding. ${ }^{86}$ Penentuan proporsi tersebut bisa dilakukan dengan cara memperkirakan besaran biaya pengangkatan satu barel. ${ }^{87}$ Berdasarkan pada pemikiran tersebut, para Pembanding menjelaskan bagaimana proporsi mereka terhadap terjadinya pencemaran.

Para Pembanding menyatakan bahwa upaya pemindahan barel yang dilakukan pemerintah terdiri dari empat tahap, di mana masing-masing tahap saling berkaitan dengan pemulihan pada parit-parit dengan lokasi yang berbeda. Parit-parit tersebut terletak di area-area yang berbeda dengan tempat pembuangan limbah, namun para Pembanding tidak menjelaskan jarak antara parit-parit tersebut. Berdasarkan gambaran tersebut, para Pembanding menegaskan bahwa biaya pemulihan yang dilakukan pemerintah dapat dibagi karena adanya bukti yang menjelaskan: ${ }^{88} 1$ ). Total jumlah barel yang diangkat di setiap tahapan; 2). Jumlah barel dalam masing-masing tahap yang dapat dikaitkan dengan para Pembanding; dan 3). Total pengeluaran biaya yang berkaitan dengan masing-masing tahapan. Lebih spesifik lagi, masing-masing Pembanding memberikan penekanan pada pernyataan Majelis Hakim di pengadilan tingkat pertama, yaitu: ${ }^{89} 1$ ). Majelis Hakim menemukan bahwa American Cyanamid bertanggung jawab atas 10 barel B3 yang ditemukan di tempat pembuangan; dan 2). Untuk Rohm and Haas, Majelis Hakim setuju dengan estimasi pemerintah, yakni Rohm and Haas berkontribusi sebanyak 49 barel dan 303 ember limbah. Para Pembanding kemudian menambahkan bahwa 10 barel limbah milik American Cyanamid tersebut ditemukan pada tahap ke-2 dan 49 barel dan 303 ember limbah milik

85 Ibid.

86 Ibid., hal. 590.

87 Ibid.

88 Ibid.

89 Ibid. 
Rohm and Haas ditemukan di tahap ke-3. Pada akhirnya, para Pembanding menyimpulkan bahwa American Cyanamid seharusnya hanya bertanggung jawab terhadap sebagian kecil \$ 995.697,30 yang dikeluarkan pemerintah untuk mengangkat sekitar 4.500 barel pada tahap ke-2..$^{0}$ Sedangkan untuk Rohm and Haas, para Pembanding menyimpulkan bahwa Rohm and Haas seharusnya hanya bertanggung jawab untuk sebagian kecil \$ 58.237 yang dikeluarkan pemerintah dalam pengangkatan sekitar 3.300 barel pada tahap ke-3. ${ }^{91}$

Majelis Hakim di pengadilan tingkat banding menolak pernyataan dari para Pembanding tersebut. Majelis hakim di pengadilan tingkat banding telah mencermati pernyataan Majelis Hakim di pengadilan tingkat pertama mengenai jumlah limbah B3 yang dapat dikaitkan dengan masing-masing Pembanding. ${ }^{92}$ Menurut Majelis Hakim pengadilan tingkat banding, Majelis Hakim di pengadilan tingkat pertama tidak bermaksud untuk menyatakan bahwa para Pembanding hanya berkontribusi sebanyak 49 barel (Rohm and Haas) dan 10 barel (American Cyanamid). ${ }^{93}$ Akan tetapi hanyalah sejumlah 49 dan 10 barel limbah yang dapat secara meyakinkan dikaitkan kepada para Pembanding. ${ }^{94}$ (penebalan berasal dari penulis)

John Leo memberikan kesaksian bahwa dari sekitar 10.000 barel yang diangkat selama empat tahapan, hanya tiga ratus sampai empat ratus barel yang memiliki tanda yang dapat ditelusuri asalnya. ${ }^{95}$ John Leo juga memberikan kesaksian bahwa bukan hanya tidak adanya tanda yang dapat dibaca yang menghalangi pemerintah untuk mengidentifikasi sumber

$90 \quad$ Ibid.

91 Ibid.

92 Pernyataan Majelis Hakim di pengadilan tingkat pertama mengenai jumlah limbah B3 yang dapat dikaitkan dengan para pembanding didasarkan pada kesaksian dari John Leo, insinyur yang dipekerjakan oleh pemerintah untuk meninjau proses pelaksanaan pemulihan. Lihat dalam Ibid.

93 Ibid.

94 Ibid.

95 Hal ini tidak mengejutkan mengingat di tempat pembuangan limbah B3 tersebut terjadi kebakaran besar. Kebakaran tersebut menyebabkan barel berisi limbah cair tersebut bocor sehingga limbah-limbah cair dari barel-barel yang berbeda bercampur dan musnah di luar barelnya. Lihat: Ibid., hal. 591. 
mayoritas besar barel tersebut, tetapi juga dikarenakan tingkat bahaya dalam menangani barel-barel tersebut. Berdasarkan fakta bahwa sebagian besar limbah tidak dapat diidentifikasi sumbernya, dan bahwa para Pembanding yang memiliki beban untuk mempertanggungjawabkan ketidakpastian tersebut, Majelis Hakim pengadilan tingkat banding berpendapat bahwa Majelis Hakim pengadilan tingkat pertama tidak melakukan kesalahan dalam memutuskan bahwa para pembanding bertanggung jawab secara tanggung renteng (joint and several liability). ${ }^{96}$ (penebalan berasal dari penulis)

\section{Gugatan Tanggung Renteng Dalam Pencemaran Udara dari Karhutla}

Setelah melalui pembahasan gugatan tanggung renteng baik di dalam sistem hukum Indonesia dan perbandingannya dengan sistem hukum common law, pada bagian ini penulis akan membahas perihal relevansi gugatan tanggung renteng terhadap peristiwa pencemaran udara dari karhutla. Pembahasan pada bagian ini akan meliputi para pihak yang bersengketa, kerugian, hubungan kausalitas, dan aturan-aturan hukum yang dapat memudahkan gugatan tanggung renteng terhadap pencemaran udara dari karhutla.

\subsection{Para Pihak Dalam Sengketa Pencemaran Udara dari Karhutla}

Seperti yang sudah dijelaskan di dalam bagian nomor 2 dan 3 dalam tulisan ini, gugatan tanggung renteng dapat dilakukan oleh pihak yang merasa dirugikan akibat perbuatan sekelompok orang. Dalam kasus pencemaran udara dari karhutla, masyarakat yang menderita kerugian karena pencemaran udara yang timbul dari karhutla dapat menggugat sekelompok orang, dalam hal ini badan hukum, yang dinilai telah menyebabkan terjadinya pencemaran udara tersebut. Misalnya di Provinsi Sumatera Selatan, masyarakat Kota Palembang yang menderita kerugian akibat pencemaran udara dari karhutla dapat menggugat secara tanggung renteng perusahaan-perusahaan Hutan Tanaman Industri dan perkebunan sawit yang konsesinya terbakar dan mengeluarkan asap pencemar udara.

$96 \quad$ Ibid. 
Penggugat tidak diharuskan mengetahui dengan pasti jumlah dan pihak atau perusahaan mana saja yang telah menyebabkan terjadinya pencemaran udara dari karhutla. Misalnya, Penggugat dapat menggugat secara tanggung renteng hanya tiga perusahaan penyebab terjadinya pencemaran udara dari karhutla yang merugikan penggugat. Tiga perusahaan tersebut dapat diminta untuk membayar 100\% kerugian yang diderita oleh Penggugat. Perihal kemungkinan adanya pihakpihak lain yang sebenarnya berkontribusi juga terhadap kerugian Penggugat, hal ini menjadi beban Tergugat untuk menarik pihak-pihak tersebut ke dalam proses persidangan untuk ikut bertanggung jawab atas kerugian yang diderita Penggugat.

Gugatan tanggung renteng meringankan beban Penggugat untuk melakukan upaya memperoleh kompensasi atas kerugian yang dideritanya dengan memindahkan urusan pembagian pertanggungjawaban kepada para Tergugat. Hal ini relevan dengan kasus pencemaran udara dari karhutla mengingat informasi perihal pihak-pihak yang dianggap sebagai penyebab terjadinya pencemaran udara dari karhutla seringkali sulit diperoleh terutama oleh korban yang menderita kerugian. ${ }^{97}$

Selain itu, karakteristik kerugian akibat pencemaran udara dari karhutla yang tidak dapat dibagi-bagi (indivisible) menjadi relevan untuk dilakukannya gugatan tanggung renteng. Kerugian dari pencemaran udara pada kesehatan misalnya tidak dapat dipisah-pisah atau dibagi-bagi kepada sekian pihak yang dinilai sebagai penyebabnya. Mayoritas jenis kerugian kesehatan yang diderita akibat pencemaran udara dari karhutla juga memiliki kesamaan, misalnya penyakitpenyakit pada saluran pernafasan seperti ISPA. Oleh karena itu, gugatan secara tanggung renteng oleh masyarakat ${ }^{98}$ yang menderita akibat pencemaran udara dari

97 Misalnya Kementerian Lingkungan Hidup dan Kehutanan RI (KLHK) tidak mempublikasikan informasi yang lengkap perihal nama-nama perusahaan yang lahannya terbakar pada saat periode musim kemarau di Tahun 2015. Lihat dalam: "Pemerintah Tak Akan Buka Nama Perusahaan yang Bakar Hutan", http://nasional.kompas.com/ read/2015/10/26/13254171/Pemerintah.Tak.Akan.Buka.Nama.Perusahaan.yang.Bakar. Hutan?utm_source=RD\&utm_medium=inart\&utm_campaign=khiprd, diakses tanggal 12 April 2016. Selain nama-nama perusahaan, untuk melakukan gugatan masyarakat membutuhkan pula informasi-informasi lainnya seperti luas lahan perusahaan yang terbakar, jenis lahan yang terbakar, dan tingkat pencemaran udara yang terjadi pada saat asap timbul dari karhutla.

98 Adanya kesamaan fakta atau peristiwa, dasar hukum, serta jenis tuntutan di antara masyarakat yang menderita kerugian akibat pencemaran udara dari karhutla, maka 
karhutla kepada sekelompok perusahaan yang dianggap sebagai penyebabnya sangat mungkin untuk dilakukan.

\subsection{Kerugian Akibat Pencemaran Udara dari Karhutla}

Perihal kerugian akibat pencemaran udara dari karhutla, penulis berpendapat bahwa terdapat beberapa jenis kerugian yang relevan untuk dimintakan ganti rugi kepada para pihak yang dianggap sebagai penyebabnya. Beberapa jenis kerugian tersebut misalnya:

- Kerugian biaya yang harus dikeluarkan untuk melakukan pengobatan terhadap penyakit-penyakit yang diderita akibat pencemaran udara dari karhutla (contohnya ISPA); ${ }^{99}$ dan

- Kerugian tidak dapat dilaksanakannya kegiatan belajar mengajar karena indeks pencemaran udara yang sudah mencapai tingkat bahaya. ${ }^{100}$

Kedua jenis kerugian ini dapat dibatasi ke dalam suatu rentang waktu, misalnya dimulai pada saat indeks standar pencemar udara berada pada tingkat bahaya sampai indeks standar pencemar udara kembali pada keadaan aman. Selain itu, penghitungan kerugiannya juga bisa dibatasi pada kerugian akibat pencemaran udara yang terjadi pada tahun 2015 saja. Menurut penulis, kedua jenis kerugian ini dapat dijadikan sebagai bagian dari posita dan petitum dalam gugatan tanggung renteng atas pencemaran udara dari karhutla.

\subsection{Kausalitas}

Kausalitas dalam gugatan tanggung renteng terhadap pencemaran udara dari karhutla akan menjadi tantangan tersendiri bagi Penggugat. Menurut Smith dan Shearman, sebagaimana dikutip oleh Elena, kausalitas telah dinilai sebagai the

gugatan tanggung renteng ini bisa dilakukan melalui gugatan perwakilan kelompok (class action). Hal ini serupa dengan kasus Mandalawangi atau kasus Aswardi, dkk. vs PT. Cahaya Bintan Abadi, dkk. dalam bagian nomor 2 tulisan ini.

99 ISPA merupakan salah satu contoh penyakit yang dominan diderita oleh masyarakat yang terpapar asap dari karhutla. Lihat misalnya dalam: Pusdatin Kementerian Kesehatan RI, op. cit., hal. $3-4$.

100 Keputusan agar para siswa melakukan kegiatan belajar untuk sementara di rumah terjadi juga karena pencemaran udara dari karhutla. Lihat misalnya dalam: "Sekolah di Sumsel Masih Diliburkan Akibat Asap", http://www.bbc.com/indonesia/berita indonesia/2015/09/150918_indonesia_asap, diakses tanggal 12 April 2016. 
greatest obstacle to the majority of plaintiffs' ${ }^{101}$

Berkaitan dengan kausalitas, pandangan Smith dan Shearman terhadap kausalitas dalam gugatan atas perubahan iklim menarik untuk ditelisik. Menurut mereka, sebagaimana dikutip oleh Elena, terdapat dua isu utama berkaitan dengan kausalitas. Pertama, pertanyaan perihal apakah persyaratan-persyaratan hukum dan probabilitas dari kausalitas sudah layak atau cukup fleksibel untuk mengakomodasi kompleksitas yang inheren di dalam ilmu pengetahuan mengenai pemanasan global. Kedua, pertanyaan mengenai apakah bukti ilmiah yang ada sudah cukup untuk membuktikan adanya kausalitas. ${ }^{102}$

Berkaitan dengan isu yang pertama, pandangan Wibisana mengenai kausalitas dalam pertanggungjawaban mutlak (strict liability) bisa menjadi jawaban terhadap isu tersebut. Menurut Wibisana, yang mengutip pendapat dari Vernon Palmer, strict liability memiliki ciri khas yang berbeda dengan pertanggungjawaban dengan kesalahan (negligence) ${ }^{103}$ dalam hal pembuktian kausalitas. ${ }^{104}$ Ciri khas yang pertama adalah pembuktian kausalitas dari sisi penyebab faktual (cause in fact) dalam strict liability dilakukan secara sederhana. Maksudnya adalah pengadilan tidak perlu membuktikan kausalitas dengan pengujian yang bersifat hipotetis (hypothetical atau counterfactual). ${ }^{105}$ Dengan kata lain, pembuktian penyebab faktual dalam strict liability terfokus pada pertanyaan apakah kerugian Penggugat secara faktual disebabkan oleh kegiatan yang dilakukan oleh Tergugat. ${ }^{106}$

101 Elena Kosolapova, “Liability for Climate Change-Related Damage in Domestic Courts: Claims for Compensation in the USA", dalam Michael Faure and Marjan Peeters (eds), Climate Change Liability, (Edward Elgar, Cheltenham UK: 2011), hal. 197.

102 Ibid., hal. 198.

103 Sebenarnya pertanggungjawaban berdasarkan kesalahan (fault-based liability) tidak hanya dalam bentuk negligence, namun juga ada dalam bentuk intentional tort. Fault atau kesalahan dalam intentional tort ditunjukan dengan kesengajaan pihak Tergugat untuk menghasilkan kerugian pada Penggugat sedangkan fault pada negligence ditunjukan dengan pelanggaran terhadap aturan kehati-hatian yang layak (reasonable care) yang hidup di dalam masyarakat. Lihat dalam: Andri G. Wibisana, op. cit., hal. 9.

104 Ibid., hal. 31.

105 Pembuktian penyebab faktual dalam negligence biasanya dilakukan melalui pengujian "but for". Pengujian tersebut dilakukan dengan mengajukan pertanyaan hipotetis seperti: apakah kerugian akan tetap terjadi seandainya Tergugat melakukan perbuatan yang berbeda dengan perbuatan yang ia lakukan? Pengujian seperti ini dianggap counterfactual karena pada kenyataannya Tergugat tidak melakukan perbuatan yang berbeda seperti yang ada dalam pertanyaan hipotetis tersebut. Lihat: Ibid., hal. 32.

106 Ibid. 
Ciri khas yang kedua adalah perihal kausalitas dari sisi legal atau yang biasa dikenal dengan istilah proximate cause. ${ }^{107}$ Dalam strict liability, pembuktian proximate cause tidak berada pada ranah pembuktian kausalitas lagi akan tetapi berpindah pada pembuktian dalam konteks abnormally dangerous test. Jadi pembuktian proximate cause dilakukan untuk menentukan apakah strict liability dapat diterapkan atau tidak berdasarkan karakteristik abnormally dangerous dari usaha dan/atau kegiatan Tergugat. ${ }^{108}$

Proximate cause juga biasanya berkaitan dengan pengujian ada atau tidaknya intervening cause (penyebab lain yang mengintervensi) atau superseding cause (penyebab eksternal yang dianggap lebih mempengaruhi terjadinya kerugian dibandingkan dengan kegiatan Tergugat). Dalam strict liability, intervening cause atau superseding cause dikanalisasi menjadi persoalan pembelaan (defense) bagi Tergugat dan bukan lagi menjadi beban pembuktian kausalitas oleh Penggugat. ${ }^{109}$ Satu hal lagi yang berkaitan dengan proximate cause adalah perihal foreseeability dari resiko usaha dan/atau kegiatan dari Tergugat. ${ }^{110}$ Menurut MacAyeal, sebagaimana dikutip oleh Wibisana, dalam strict liability unsur foreseeability dari resiko usaha dan/atau kegiatan Tergugat bersifat objektif. ${ }^{111}$ Dengan kata lain, ukuran untuk

107 Proximate cause merupakan bentuk kausalitas yang melengkapi kausalitas dalam bentuk cause in fact atau penyebab faktual. Dikatakan melengkapi karena pembuktian adanya kausalitas dalam bentuk penyebab faktual saja masih belum cukup untuk membuat seseorang dinyatakan bertanggung jawab atas suatu kerugian tertentu. Setelah membuktikan adanya penyebab faktual, Penggugat masih harus membuktikan adanya proximate cause atau disebut juga legal cause. Suatu perbuatan dapat dikatakan sebagai proximate cause jika perbuatan tersebut merupakan sebab yang cukup "dekat" dengan kerugian Penggugat. Lihat: Ibid., hal. 29. Ada dua pendekatan yang bisa digunakan dalam membuktikan adanya proximate cause, yakni dari sisi ada atau tidaknya intervening dan superseding causes serta dari sisi foreseeability terjadinya kerugian. Dua pendekatan proximate cause ini akan dibahas dalam paragraf berikutnya.

108 Ibid. Biasanya ruang lingkup pertanggungjawaban dalam strict liability yang merupakan bagian dari proximate cause sudah ditentukan oleh undang-undang. UU PPLH misalnya menentukan bahwa ruang lingkup pertanggungjawaban dalam strict liability meliputi tindakan, usaha, dan/atau kegiatan yang menggunakan B3, menghasilkan dan/atau mengelola limbah B3, dan/atau yang menimbulkan ancaman serius terhadap lingkungan hidup. Lihat dalam UU No. 32 Tahun 2009 tentang Perlindungan dan Pengelolaan Lingkungan Hidup, LN Tahun 2009 No. 140, TLN No. 5059, Pasal 88.

Ibid., hal. 33.

110 Syarat foreseeability dalam proximate cause merupakan sebuah syarat bahwa kerugian yang terjadi merupakan hal yang sudah dapat diperkirakan sebelumnya. Lihat: Ibid.

111 Ibid. 
menentukan foreseeability dalam strict liability adalah pandangan secara umum/ luas terhadap risiko dari sebuah kegiatan tertentu. ${ }^{112}$

Maksud dari pemaparan di atas adalah untuk menunjukan bahwa tantangan pembuktian kausalitas dalam gugatan tanggung renteng terhadap pencemaran udara dari karhutla dapat dijawab dengan menggunakan dasar gugatan strict liability. Penulis memperkirakan bahwa tantangan dalam gugatan tanggung renteng terhadap pencemaran udara dari karhutla terletak salah satunya dari sisi pembuktian intervening cause atau superseding cause. Salah satu karakteristik dalam gugatan pencemaran lingkungan adalah adanya pencemar-pencemar lain di luar kontribusi pencemaran yang dilakukan oleh Tergugat. Zat-zat pencemar dari pihak di luar Tergugat bercampur di udara dengan zat-zat pencemar yang dikeluarkan oleh Tergugat. ${ }^{113}$ Karakteristik ini lah yang bisa menjadi intervening cause dalam hal pencemaran udara dari karhutla.

Akan tetapi, dengan dasar gugatan strict liability, pembuktikan ada atau tidaknya pihak lain yang lebih berperan terhadap kerugian akibat pencemaran udara yang diderita Penggugat kini tidak lagi menjadi beban pembuktian bagi Penggugat. Dalam strict liability, perihal intervening cause tersebut menjadi bagian pembelaan Tergugat. Tergugat lah yang harus membuktikan bahwa terdapat sebab atau pihak lain yang lebih berperan terhadap terjadinya kerugian akibat pencemaran udara yang diderita oleh Penggugat.

Selain itu, Penggugat mungkin akan dihadapkan dengan minimnya kepastian ilmiah dalam membuktikan hubungan kausalitas antara pencemaran udara dari karhutla dengan kerugian yang diderita oleh Penggugat. Minimnya kepastian ilmiah ini misalnya dalam membuktikan bahwa dampak pencemaran udara yang diderita Penggugat memang disebabkan oleh asap yang timbul dari karhutla dalam konsesi sekelompok Tergugat. Selain itu, Penggugat juga mungkin mengalami kesulitan dalam menunjukan bukti-bukti bahwa asap yang dihasilkan akibat dari karhutla di dalam konsesi Tergugat merupakan kontributor terbesar terhadap kerugian yang dialami Penggugat dibandingkan dengan pencemaran udara dari sumber-sumber lainnya.

112 Ibid., hal. 34.

113 Kontribusi zat-zat pencemar udara di luar karhutla misalnya berasal dari alat transportasi atau berasal dari kegiatan yang mengeluarkan emisi sejenis dengan karhutla. 
Penerapan asas kehati-hatian dapat menjadi jawaban bagi persoalan ini. Menurut Elena, apabila pengadilan berkehendak untuk menerapkan asas kehatihatian dalam sengketa perubahan iklim, maka minimnya kepastian ilmiah seharusnya tidak memutuskan hubungan kausalitas di dalam sengketa tersebut. ${ }^{114}$ Maka dalil penerapan asas kehati-hatian dalam gugatan tanggung renteng terhadap pencemaran udara dari karhutla bisa membantu Penggugat dalam pembuktian kausalitas.

\section{Kesimpulan}

Berdasarkan pembahasan dalam tulisan ini, dapat dilihat bahwa masyarakat dapat melakukan gugatan untuk memperoleh ganti rugi atas kerugian yang diderita akibat pencemaran udara dari karhutla. Gugatan tanggung renteng menjadi bentuk gugatan yang relevan mengingat kerugian yang terjadi diakibatkan oleh lebih dari satu pihak. Gugatan tanggung renteng memberikan jalan bagi penggugat untuk menggugat beberapa perusahaan saja untuk membayar keseluruhan kerugian yang diderita. Pembelaan kurangnya pihak dalam gugatan tanggung renteng menjadi tidak relevan mengingat kemungkinan minimnya informasi yang dimiliki Penggugat mengenai pihak mana saja yang menyebabkan terjadinya kerugian. Penarikan pihak-pihak lain yang dinilai ikut berkontribusi terhadap kerugian yang diderita oleh Penggugat menjadi beban dari Tergugat.

Tulisan ini juga memperlihatkan bahwa sudah ada praktik-praktik gugatan tanggung renteng terhadap perbuatan melawan hukum di bidang lingkungan hidup seperti kasus Mandalawangi dan Aswardi, dkk. melawan PT. Cahaya Bintan Abadi, dkk. Gugatan tanggung renteng juga berlaku di dalam sistem hukum common law dengan istilah joint and several liability. Putusan pengadilan dalam erkara United States v. Chem Dyne Corp. dan O'Neil v. Picillo menjadi contoh putusan di mana dalil joint and several liability diterima di dalam sistem hukum common law.

114 Elana Kosolapova, op. cit., hal. 199. Elena memberikan beberapa contoh penerapan asas kehati-hatian seperti dalam kasus Gray $v$ Minister for Planning and Ors (2006) NSWELC 720; Walker v Minister for Planning (2007) NSWLEC 741; dan Gippsland Coastal board v South Gippsland SC \& Ors (2008) VCAT 1545. 
Adanya peluang gugatan tanggung renteng terhadap pencemaran udara dari karhutla diiringi juga dengan adanya tantangan dalam hal pembuktian kausalitas. Tantangan tersebut misalnya ketika zat-zat pencemar dari sumber di luar karhutla bercampur dengan zat-zat pencemar yang bersumber dari karhutla. Keadaan tersebut bisa menjadi intervening cause yang pada akhirnya melemahkan pembuktian kausalitas oleh Penggugat. Namun kombinasi gugatan tanggung renteng dengan strict liability dapat membantu Penggugat dalam pembuktian kausalitas karena beban adanya intervening cause tersebut berpindah kepada Tergugat dalam bentuk pembelaan (defense). Di sisi lain, penerapan asas kehati-hatian dalam gugatan ini juga dapat membantu ketika Penggugat diliputi minimnya kepastian ilmiah dalam membuktikan hubungan kausalitas antara kerugian yang diderita dengan pencemaran udara yang berasal dari kegiatan Tergugat.

Pada akhirnya peluang-peluang yang disampaikan dalam tulisan ini menjadi strategis untuk dilakukan agar terjadi perubahan keadaan bagi masyarakat yang menderita kerugian akibat pencemaran udara dari karhutla. Perubahan keadaan tersebut adalah perubahan dari keadaan tidak adanya pertanggungjawaban dari para pencemar (no liability) menuju dilaksanakannya pertanggungjawaban dari pencemar atas kerugian yang diderita oleh masyarakat. 


\section{DAFTAR PUSTAKA}

Agustina, Rosa. 2003. Perbuatan Melawan Hukum. Pascasarjana FHUI. Jakarta. bbc.com, "Asap Kebakaran Hutan Sampai Jakarta", http://www.bbc.com/ indonesia/berita_indonesia/2015/10/151024_indonesia_jakarta_kabutasap, diakses pada tanggal 21 Juni 2016.

bbc.com. "Sekolah di Sumsel Masih Diliburkan Akibat Asap", http://www.bbc. com/indonesia/berita_indonesia/2015/09/150918_indonesia_asap, diakses tanggal 12 April 2016.Kompas. "Longsor Paling Mematikan”. 19 Desember 2015.

Eyes on the Forest. 2015. “Terlibat Kejahatan Kemanusiaan, Para Pelaku Layak

Diseret ke Pengadilan", http://eyesontheforest.or.id/attach/Laporan \%20 Ringkas\%20EoF\%20(Dec2015) \% 20Pembakaran \% 20hutan \% 20lahan \% 20 di\%2037\%20lokasi\%20Riau\%20FINAL2.pdf, diakses tanggal 21 Maret 2016.

Gegana, Giska Matahari. 2011. “Penerapan Prinsip Tanggung Renteng Dalam Hal

Kreditur Melakukan Wanprestasi Terhadap Perjanjian Kredit Sindikasi". Skripsi FHUI. Depok.

Indonesia. Undang-Undang No. 32 Tahun 2009 tentang Perlindungan dan Pengelolaan Lingkungan Hidup.

Kitab Undang-Undang Hukum Perdata (Burgerlijk Wetboek voor Indonesie).

kompas.com. "Pemerintah Tak Akan Buka Nama Perusahaan yang Bakar Hutan", http://nasional.kompas.com/read/2015/10/26/13254171/Pemerintah.Tak. Akan.Buka.Nama.Perusahaan.yang.Bakar.Hutan?utm_source=RD\&utm medium=inart\&utm_campaign=khiprd, diakses tanggal 12 April 2016.

Kosolapova, Elena. 2011. "Liability for Climate Change-Related Damage in Domestic Courts: Claims for Compensation in the USA", dalam Michael Faure and Marjan Peeters. (eds). Climate Change Liability. Cheltenham UK: Edward Elgar.

Law Commission of New Zealand. 2012. "Review of Joint and Several Liability". Wellington: Issues Paper 32. 
Legal Information Institute. “Motion For Judgment As A Matter Of Law". https:// www.law.cornell.edu/wex/motion_for_judgment_as_a_matter_of_law. Cornell University Law School. (diakses pada 31 Juli 2016).

Miller, Jeffrey G. dan Craig N. Johnson. 2005. (2 ${ }^{\text {nd }}$ Edition). The Law of Hazardous Waste Disposal and Remediation: Cases-Legislation-Regulation-Policies. St. Paul: Thomson West.

mongabay.co.id. "Kasasi Ditolak, Kalista Alam Harus Bayar Rp 366 Miliar, Menteri Siti: Penuhi Rasa Keadilan", http://www.mongabay.co.id/2015/09/13/ kasasi-ditolak-kalista-alam-harus-bayar-rp366-miliar-menteri-siti-penuhirasa-keadilan/, diakses tanggal 24 Maret 2016.

Pengadilan Negeri Bandung. Dedi, dkk. vs PT. Perhutani, dkk. Putusan PN Bandung No. 49/Pdt.G/2003/PN.BDG.

Pengadilan Negeri Meulaboh. Menteri LHK vs PT. Kallista Alam. Putusan PN Meulaboh No. 12/PDT.G/2012/PN.MBO.

Pengadilan Negeri Tanjung Pinang. Aswardi, dkk. vs PT. Cahaya Bintan Abadi, dkk. Putusan PN Tanjung Pinang No. 26/PDT.G/2009/PN.TPI.

Pusdatin Kementerian Kesehatan RI. 2015. "Masalah Kesehatan Akibat Kabut Asap Kebakaran Hutan dan Lahan Tahun 2015", http://www.depkes.go.id/ resources/download/pusdatin/infodatin/infodatin-asap.pdf, diakses tanggal 16 Maret 2016.

republika.co.id. "Ratusan Perusahaan Diduga Terlibat Pembakaran Hutan", http:// nasional.republika.co.id/berita/nasional/umum/16/01/22/o1cgje361ratusan-perusahaan-diduga-terlibat-pembakaran-hutan, diakses tanggal 21 Maret 2016.

Santosa, Mas Achmad. 1998. “Teori Pertanggungjawaban Pencemaran (Liability Theories)" dalam Sulaiman N. Sembiring. (ed.). Hukum dan Advokasi Lingkungan. ICEL.

Uslegal.com. "Erie Doctrine". http://civilprocedure.uslegal.com/choice-of-law/ erie-doctrine/ (diakses pada 31 Juli 2016). 
Wibisana, Andri Gunawan. “Menggugat Kebakaran Hutan”. Kompas. Rabu 7 Oktober 2015.

Wibisana, Andri Gunawan. “Pertanggungjawaban Perdata dan Pembuktian Dalam Hukum Lingkungan Indonesia". Makalah disampaikan dalam lokakarya kebakaran hutan dan lahan oleh Walhi. Jakarta, Indonesia: Eksekutif Nasional Walhi, Oktober 2015. 
